Florida International University FIU Digital Commons

7-17-1991

\title{
The effect of nutrition education on the nutrition knowledge of college athletes
}

Maria Guadalupe Bermudez

Florida International University

DOI: $10.25148 /$ etd.FI14051119

Follow this and additional works at: https://digitalcommons.fiu.edu/etd

Part of the Dietetics and Clinical Nutrition Commons

\section{Recommended Citation}

Bermudez, Maria Guadalupe, "The effect of nutrition education on the nutrition knowledge of college athletes" (1991). FIU Electronic Theses and Dissertations. 1768.

https://digitalcommons.fiu.edu/etd/1768

This work is brought to you for free and open access by the University Graduate School at FIU Digital Commons. It has been accepted for inclusion in FIU Electronic Theses and Dissertations by an authorized administrator of FIU Digital Commons. For more information, please contact dcc@fiu.edu. 


\title{
ABSTRACT OF THE THESIS
}

\author{
The Effect of Nutrition Education \\ on the Nutrition Knowledge \\ of College Athletes
}

by

Maria Guadalupe Bermudez

Florida International University, 1991

Miami, Florida

Michele W. Keane, Major Professor

The relationship between nutrition and athletic performance has become a topic of increasing interest in college athletics. This study assessed the effect of nutrition education on the nutrition knowledge and dietary adequacy of female and male college athletes through a pre-test/post-test, control group design. Six weekly lessons were offered to the experimental groups. For female athletes, a two sample t-test indicated significant differences on gain scores for the experimental group $(p<0.02)$ and mean differences (post minus pre-test) between experimental and control groups $(\mathrm{p}<0.03)$. For male athletes, no significant differences on gain scores for the experimental group $(p<0.9)$ or the control group $(\mathrm{p}<0.8)$ were found. No significant improvements in nutritional adequacy of the diet were noted for female or male athletes. Nutrition education provided through small group lectures resulted in a significant improvement in nutrition knowledge for female athletes. A different educational approach to enhance nutrition knowledge for these male athletes may be warranted. 


\title{
FLORIDA INTERNATIONAL UNIVERSITY \\ Miami, Florida
}

\author{
The Effect of Nutrition Education \\ on the Nutrition Knowledge \\ of College Athletes
}

\begin{abstract}
A thesis submitted in partial satisfaction of the
requirements for the degree of Master of Science

in Dietetics and Nutrition

by

Maria Guadalupe Bermudez
\end{abstract}


To Professors: Michele W. Keane

Katharine R. Curry

Richard Lopez

This thesis, having been approved in respect to form and mechanical execution, is referred to you for judgement upon its substantial merit.

William J. Keppler

Dean, College of Health

The thesis of Maria Guadalupe Bermudez is approved.

Katharine R. Curry

Richard Lopez

Michele W. Keane, Major Professor

Date of Examination: July 17, 1991

Richard L. Campbell

Division of Graduate Studies

Florida International University, 1991 


\section{DEDICATION}

To my parents,

Jesus and Goyita Bermudez 


\section{ACKNOWLEDGEMENTS}

This research study wouldn't have been possible without the dedication, support and advice of Dr. Michele W. Keane. I don't have enough words to express my gratitude and admiration. Thank you so much Dr. Keane!

To my Thesis Committee, Dr. Katharine R. Curry and Dr. Richard Lopez, I'm also in debt. Their encouragement and support during this study won't be forgotten.

A special thank you for Dr. Paulette Johnson. Her advice on statistical analyses is very much appreciated.

To the University of Miami's Athletic Department, Andy Clary and Doris Paloma, for their availability and interest in sports nutrition.

And a loving thank you to my brother and sister, Luis and Ines Garcia. 


\section{TABLE OF CONTENTS}

Page

CHAPTER ONE: STATEMENT OF THE PROBLEM

Statement of the problem 1

Statement of the hypotheses 4

Limitations of the study 4

CHAPTER TWO: REVIEW OF THE LITERATURE

Review of the literature $\quad 6$

$\begin{array}{ll}\text { College students } & 7\end{array}$

$\begin{array}{lr}\text { Nutrition knowledge of college athletes } & 8\end{array}$

Dietary intake and practices of college athletes 11

$\begin{array}{ll}\text { Efficacy of nutrition education } & 13\end{array}$

CHAPTER THREE: METHODS AND PROCEDURES

$\begin{array}{ll}\text { Setting } & 15\end{array}$

$\begin{array}{ll}\text { Subjects } & 15\end{array}$

Instruments:

$\begin{array}{lr}\text { Nutrition knowledge measurement } & 16\end{array}$

$\begin{array}{ll}\text { Anthropometrics } & 17\end{array}$

$\begin{array}{ll}\text { Dietary intake } & 18\end{array}$

$\begin{array}{ll}\text { Lesson plans } & 18\end{array}$

$\begin{array}{ll}\text { Experimental design } & 19\end{array}$

$\begin{array}{ll}\text { Procedure } & 19\end{array}$

$\begin{array}{ll}\text { Data analysis } & 21\end{array}$ 
CHAPTER FOUR: RESULTS AND DISCUSSION

Results:

$\begin{array}{ll}\text { Anthropometrics } & 23\end{array}$

Nutrition knowledge level 23

$\begin{array}{lr}\text { Dietary intake } & 29\end{array}$

$\begin{array}{ll}\text { Discussion } & 35\end{array}$

CHAPTER FIVE: CONCLUSIONS AND RECOMMENDATIONS

$\begin{array}{ll}\text { Conclusions } & 42\end{array}$

$\begin{array}{ll}\text { Recommendations } & 43\end{array}$

$\begin{array}{ll}\text { REFERENCES } & 45\end{array}$

APPENDICES

$\begin{array}{ll}\text { Appendix A } & 49\end{array}$

$\begin{array}{ll}\text { Appendix B } & 55\end{array}$

$\begin{array}{ll}\text { Appendix C } & 57\end{array}$ 


\section{LIST OF TABLES}

Page

Table 1. Nutrient intake of college athletes.

Table 2.

Nutrition Achievement Test: areas and number of questions covered.

Table 3.

Experimental design: timetable.

Table 4.

Anthropometric measurements for female and male athletes at the beginning of the season. (Mean \pm standard deviation)

Table 5.

Mean pre-test and post-test scores and mean differences for female athletes.

Table 6.

Mean pre-test, post-test, and adjusted post-test scores for female athletes.

(Mean \pm standard deviation)

Table 7.

Mean pre-test and post-test scores and mean differences for male athletes.

Table 8.

Pre-test dietary intake for female $(n=19)$ and male $(n=13)$ athletes.

Table 9.

Pre-test energy nutrients distribution.

Table 10. Pre-test and post-test dietary intake for female athletes $(n=5)$.

Table 11. Pre-test and post-test dietary intake for male athletes $(n=5)$.

Table 12. Misconceptions identified upon the responses of female $(n=24)$ and male $(n=46)$ athletes. 


\section{CHAPTER ONE}

\section{STATEMENT OF THE PROBLEM}

In recent years, there has been an increasing interest in nutrition as it relates to athletic performance. It is believed by many that athletes' diets provide an adequate nutrient content simply because of the greater amount of food consumed. However, there is no evidence that athletes select healthier diets than less active people (1-2). Athletes are often reported to struggle with inappropriate, self-prescribed diets (3-4).

The nutritional requirements of an athlete are not significantly different from those of the average person, except for the energy requirement due to an increased energy expenditure during training and competition (5-9). However, there is no objective evidence that athletic performance can be improved by modifying a basically balanced and nutritious diet $(7,9)$.

A population that has received much attention regarding nutrition and performance is the college level athlete $(2,10-13)$. Nutrition misconceptions and fallacies appear to be prevalent among college athletes $(12,14-16)$. Poor dietary behaviors with potential risk of marginal nutrient intakes have been identified for both male and female college athletes $(2,12-14,17)$.

Football players, reported to consume huge amounts of food, have been noted to have diets that are nutritionally inadequate $(2,13,18)$. Diets of female basketball players have been shown to supply marginal nutrient intakes as well (17). From a review of the 
literature, it appears that the athletes' eating patterns are, at least in part, the result of inadequate nutrition information.

Sound nutrition knowledge and food practices play an important role in athletic performance (18-19). It has been suggested that dietary regimes to support physical achievement and athletic excellence require a level of nutrition knowledge and practice that may not be present among the athletes, coaches or trainers $(6,8,15,20-21)$.

Coaches and athletic trainers often assume responsibility for controlling and guiding the dietary practices of athletes. They rarely have formal training in nutrition and probably do not have the time or expertise needed to stay well-informed of developments in nutrition $(6,8,10,19)$. Short and Short (2) have said: "There is no area of nutrition where faddism, misconceptions and ignorance are more obvious than in athletics."

Health and sports magazines, television and radio have been cited as the most frequent media-related sources of information for both coaches and athletes (10-11,22-23). The reliability of these sources is questionable. Even informed consumers often have trouble sorting myth from truth from these sources. The result may be misconceptions leading to nutrition practices which lack a sound scientific base.

Communication with athletes and athletic departments to work toward improved nutrition practices is a vital role for registered dietitians. Their contribution in the area of nutrition education and dietary counseling is indispensable.

Since nutrition intervention may improve the nutrition knowledge and dietary practices of college athletes and many athletic departments do not have the professional services of a registered dietitian, the effects of nutrition education for college athletes during 
training and/or competition needs to be investigated.

Appropriate advice and instruction should be available for athletes who are seeking the "nutritional edge" in their sport enabling them to avoid fallacies and myths (10). Athletes need the help of knowledgeable health professionals in sports nutrition to educate them toward better nutrition practices, safely, intelligently and effectively $(2,11-12)$.

This is an opportunity for qualified dietitians/nutritionists to be involved in group education at the college level. Potential approaches to provide appropriate nutrition information to college athletes include nutrition education classes. The goal of nutrition education in this setting is to inform athletes of the value of good nutrition and motivate them to select nutritious foods according to their preferences and needs. Appropriate food habits that will continue throughout a lifetime is the long term goal of any nutrition education program $(8,11)$.

Perhaps nutrition intervention should be addressed to specific college sports. Effectiveness of such programs can be assessed by improvement in nutrition knowledge scores, the first step for the establishment of adequate food habits. The primary purpose of this study was to investigate the effect of nutrition education on the nutrition knowledge of both college male football and female basketball players. A secondary purpose was to assess the effect of nutrition education on the nutritional adequacy of these groups of athletes. 
Statement of the hypotheses:

1. It is hypothesized that college athletes who receive nutrition education (experimental group) will demonstrate a significant improvement in nutrition knowledge (measured as test scores) when compared to college athletes who receive no nutrition education (control group).

2. It is hypothesized that college athletes who receive nutrition education will show a significant improvement of dietary adequacy when diet records, pre- and posttreatment, are compared.

\section{Limitations of the study:}

1. Subjects participating in the study were a population of convenience. All were members of the football and female basketball teams at the University of Miami.

2. The sample was selected according to the head athletic trainer's judgement. Uneven numbers of athletes for experimental and control groups were assigned and no random sampling was done.

3. The final sample size for both teams, basketball and football, is small. Results, conclusions and recommendations are addressed to this specific sample, and not applicable to the general population.

4. Reliability and validity of the Nutrition Achievement Test 4 (NAT 4) have been established (24). Questions were selected by the experimenter to fit sports nutrition topics. Twenty-eight of the 47 questions were included in the questionnaire. This may affect reliability and validity of the test instrument used. 
5. There was no control for prior nutrition knowledge.

6. Data was collected by assistants to the head athletic trainer. Although they were instructed on the purpose of the study, how to instruct athletes to keep diet records and how to administer the nutrition knowledge test, the experimenter was not present to check collection procedures.

7. Effects of nutrition education observed can not be compared to long term interventions on similar populations due to the short time period of this study ( 3 months). 


\section{CHAPTER TWO}

\section{REVIEW OF THE LITERATURE}

Athletic performance depends on several factors. These include genetic endowment, physiological and psychological training, and nutrition $(1,19)$. Without question, genetics plays a primary role in determining an athlete's performance capabilities (25).

Adequate nutrition is a necessity to enable the athlete to perform at his/her best $(1,5,11)$, and is one of the few factors that can be totally controlled by the individual. Proper nutrition can be a deciding factor in performance among athletes when all other factors are equal (25).

Interest in enhancing performance has led athletes to seek the "competitive edge" in their specific sport, often through the use of nutrition gimmicks. Contrary to popular belief there is no evidence that any nutrient given in amounts above requirements will enhance athletic performance.

The American Dietetic Association has encouraged appropriate nutrition education to promote fitness and well being (26). This professional organization recognizes the need for access to accurate nutrition information for both amateur and competitive athletes (26). It is through the Sports and Cardiovascular Nutritionists (SCAN), a practice group of the American Dietetic Association, that good nutrition has been promoted for athletes who strive for optimal performance $(19,21)$. 


\section{College students:}

Adolescents and young adults are greatly affected by peer pressure, psychological and physical maturation, and increased social activities. These factors, plus inappropriate guidance, often contribute to inadequate food patterns for this population. Exclusion of certain foods, self-prescribed low calorie diets and unrealistic views about body shape among adolescents have been noted by some authors (27-29).

Marrale et al. (27) distributed questionnaires among 1,150 undergraduate students. Of the 437 students who responded, $49 \%$ reported eating only two meals per day, $54 \%$ were currently dieting or had dieted at some time, and $47 \%$ revealed they cheat, binge and overeat while dieting.

In a similar study, Hertzler and Frary (29) reported that $43 \%$ of college students surveyed ( $n=212,63 \%$ female, $37 \%$ male) skipped breakfast (men as often as women), $81 \%$ snacked one to three times a day and $48 \%$ reported the use of vitamin/mineral supplements at the time of the survey. Hernon et al. (28) found a tendency among college women to avoid certain foods they assumed to be high in calories; they also noted infrequent eating patterns among college women whose caloric intakes were less than 1,200 kilocalories per day $(n=53)$. Their diets did not meet the RDAs for calcium (57\% RDA), iron (45\% RDA), thiamin (72\% RDA), riboflavin ( $90 \% \mathrm{RDA})$ and niacin (83\% RDA). Among the foods avoided, desserts, fat, sugar, milk products, meat, eggs, legumes, bread, and cooked/starchy vegetables were reported most often (28).

College students who have had sound dietary habits earlier in life may change their nutrition practices when they are on their own $(27,30)$. They may lack knowledge regarding 
nutritional requirements and the guidance to make wise food selections when away from home.

College athletes are not exempt to these concerns. Besides dealing with the typical changes and pressures for their age, these athletes have the combined stress of competition, constant dieting, a desire to win and fear of failure (31). Class and training schedules, schoolwork and exams add to their responsibilities.

Young athletes not only have bizarre eating habits, but are also engaged in highly competitive programs, such as those where extra weight may result in elimination from the team. All these factors have a great influence on the athlete's diet and may have a negative effect on athletic performance.

Faddism appeals more to emotions than intelligence, and athletes can easily become confused with information on eating practices (27). A need for nutrition education addressing common misconceptions among college athletes has been expressed $(2,8,11,14-$ $15,21,27,32)$.

\section{Nutrition knowledge of college athletes:}

Main sources of nutrition information cited by college athletes include popular magazines, team trainers, physicians and other players (6). Parents have also been mentioned as a primary source of information $(10,15)$.

Parr et al. (10) surveyed a total of 348 coaches and 179 athletic trainers in high school and college settings regarding their nutrition knowledge and practices. Sixty-one percent stated that they had no formal nutrition background, even though they reported 
providing nutrition information to their athletes; $78 \%$ expressed a desire for more nutrition knowledge.

A study by Wolf et al. (6) to assess the nutrition practices of coaches in the Big Ten Conference indicated that coaches recommend diet supplements, assess "proper" weight, demand weight gain or loss diets, and generally try to control the athlete's nutritional intake. Sixty-nine percent of the coaches interviewed reported rarely reading about nutrition. The remaining coaches mentioned popular magazines, team trainers, team physicians and other coaches as their main sources of information.

A review of the literature indicates that registered dietitians/nutritionists are rarely mentioned as sources for nutrition advice by athletes, coaches or trainers. Eck et al. (13) surveyed college football athletes $(n=43)$ to assess their sources of nutrition information. Fifty percent for the athletes identified athletic trainers as their main source of information while $48 \%$ reported popular magazines and newspapers. Only one football player had received nutrition information from a registered dietitian. The authors suggest athletic trainers receive further training in nutrition and strongly recommend that nutrition professionals be called upon to counsel athletes.

Nutrition knowledge of high school and college athletes has also been assessed (1415). Studies have reported that college athletes express a great degree of confidence in their own nutrition knowledge despite low scores on nutrition knowledge questionnaires (14$15)$.

Shoaf et al. (15) found a low level of nutrition knowledge among 75 male athletes who were members of the track, baseball, and/or football teams. On the nutrition section 
of the questionnaire developed by the authors, athletes scored less than $50 \%$ (43.3\% average score); some had even taken a college-level nutrition course and still scored poorly. Also, $28 \%$ of the athletes recognized the definition of carbohydrate loading, $68 \%$ had misconceptions concerning sources of carbohydrates, $37 \%$ failed to recognize a healthful recommendation for a pregame meal and $54 \%$ did not know the major functions of vitamins.

In a survey of 42 college wrestlers, Steen and McKinney (14) reported a lack of good understanding of nutrition with a mean score of $58 \%$ on a nutrition questionnaire (University of Pennsylvania Nutrition Inventory). Evidence of several misconceptions and common food fallacies were also identified. Thirty-two percent of the wrestlers avoided breads, pancakes, pasta and potatoes; $30 \%$ thought carbohydrates were important for training and performance. Only $8 \%$ believed fluids were beneficial for training and performance.

College athletes, male and female, may lack adequate knowledge to achieve the nutritional needs to support optimal performance $(14,21)$. Also, an athlete who assumes that his/her nutrition knowledge is adequate may not seek accurate information and may not be able to evaluate his/her diet for nutritional adequacy. It is important to reach individuals who are unaware that their information is incorrect (16). The misconceptions they hold may lead to inappropriate food practices.

The goal of nutrition education is to improve nutrition knowledge and to promote appropriate food habits to be continued throughout the person's lifetime. It is expected that athletes who have a basic knowledge and become familiar with the concepts and principles of nutrition will actually apply it when making food choices $(12,29)$. 


\section{Dietary intake and practices of college athletes:}

Athletes have been reported to consume a large number of kilocalories; in spite of this fact, these same diets have also been reported to be deficient in vitamin $\mathrm{A}$, vitamin $\mathrm{B}_{6}$, thiamin, iron, magnesium, zinc, calcium, iron, riboflavin, niacin and vitamin $\mathrm{C}$ (Table 1) $(2,12-14,17)$. It is possible that such deficiencies may affect athletic performance and compromise a young athlete's needs for growth and development $(5,17)$.

Athletes and coaches often believe that manipulation of an inadequate training and/ or competition diet can make a difference on athletic performance. This often leads to the use of nutritional ergogenics which are by definition any substance or food believed to enhance performance. These "nutritional ergogenic aids" include vitamin, mineral, amino acid and protein supplements (33). Opposition by nutrition professionals to the use of these products is not only their ineffectiveness, but a tendency of athletes who supplement their diets in such a manner to possess a false sense of security and thereby justify their poor eating habits (10).

Analysis of blood lipid data and diet records suggests that the large, obese college football player may have an increased risk of future coronary heart disease. Millard et al. (34) studied the coronary risk factors and nutritional status of college football players $(n=95)$. Mean intakes reported by 35 players who completed a three-day diet record were shown to be high in fat ( $35 \%$ of total kilocalories), salt ( $6 \mathrm{gm}$ sodium/day), sugar $(15 \%$ of total kilocalories) and cholesterol ( $894 \mathrm{mg} /$ day). 
Table 1. Nutrient intake of college athletes.

\begin{tabular}{|c|c|c|c|c|c|}
\hline STUDY & \begin{tabular}{c}
\multicolumn{2}{c}{ POPULATION } \\
n gender sport
\end{tabular} & $\begin{array}{l}\text { NUTRIENT } \\
\text { ADEQUACY } \\
\text { STANDARD }\end{array}$ & $\begin{array}{l}\text { ENERGY } \\
\text { NUTRIENTS }\end{array}$ & $\begin{array}{l}\text { VITAMINS } \\
\text { AND } \\
\text { MINERALS }\end{array}$ & METHOD \\
\hline $\begin{array}{l}\text { Eck et al. } \\
(1988)\end{array}$ & 43 male football & & $\begin{array}{l}35 \% \mathrm{Kcal} \text { from CHO } \\
17 \% \mathrm{Kcal} \text { from PRO } \\
48 \% \mathrm{Kcal} \text { from FAT }\end{array}$ & & Observation \\
\hline $\begin{array}{l}\text { Steen and } \\
\text { McKinney } \\
(1986)\end{array}$ & 42 male wrestling & $66 \%$ RDA & $\begin{array}{l}\% \text { of subjects } \\
\text { below standard: } \\
15 \% \text { for PRO } \\
37 \% \text { for Kcal }\end{array}$ & $\begin{array}{l}\% \text { of subjects } \\
\text { below standard: } \\
48 \% \text { for vit } \mathrm{A} \\
59 \% \text { for vit } \mathrm{B}_{6} \\
25 \% \text { for vit } \mathrm{B}_{1} \\
27 \% \text { for } \mathrm{Fe} \\
64 \% \text { for } \mathrm{Mg} \\
52 \% \text { for } \mathrm{Zn}\end{array}$ & $24 \mathrm{hr}$ recall \\
\hline $\begin{array}{l}\text { Perron and } \\
\text { Endres } \\
(1985)\end{array}$ & 31 female volleyball & $66 \%$ RDA & $\begin{array}{l}84 \% \text { RDA for Kcal } \\
\text { avg } 1799 \mathrm{Kcal} / \text { day }\end{array}$ & $\begin{array}{l}64 \% \text { RDA for } \mathrm{Ca} \\
60 \% \text { RDA for } \mathrm{Fe}\end{array}$ & $\begin{array}{l}24 \mathrm{hr} \text { recall } \\
48 \mathrm{hr} \text { record }\end{array}$ \\
\hline \multirow[t]{3}{*}{$\begin{array}{l}\text { Short and } \\
\text { Short } \\
(1983)\end{array}$} & male football & $66 \%$ RDA & $\begin{array}{l}\text { avg } 4687 \mathrm{Kcal} / \text { day } \\
\text { max } 11000 \mathrm{Kcal} / \text { day } \\
\text { max cholesterol } \\
\text { intake of } 3584 \mathrm{mg} \\
\text { mean PRO intake of } \\
201 \mathrm{~g} / \text { day (offense) } \\
191 \mathrm{~g} / \text { day (defense) }\end{array}$ & & $24 \mathrm{hr}$ recall \\
\hline & male wrestling & $66 \%$ RDA & $\begin{array}{l}\text { energy range: } \\
78-11000 \mathrm{Kcal} / \mathrm{day} \\
29-39 \% \mathrm{Kcal} \text { from } \\
\text { FAT }\end{array}$ & $\begin{array}{l}\% \text { of subjects } \\
\text { below standard: } \\
16 \% \text { for } \mathrm{Ca} \\
10 \% \text { for } \mathrm{Fe} \\
39 \% \text { for vit } \mathrm{A} \\
31 \% \text { for vit } \mathrm{B}_{1} \\
16 \% \text { for vit } \mathrm{B}_{2} \\
12 \% \text { for vit } \mathrm{B}_{3} \\
11 \% \text { for vit } \mathrm{C}\end{array}$ & $24 \mathrm{hr}$ recall \\
\hline & $\begin{array}{c}\text { female basketball } \\
\text { crew } \\
\text { lacrosse } \\
\text { swim } \\
\text { volleyball }\end{array}$ & $66 \%$ RDA & & $\begin{array}{l}\text { Poor } \mathrm{Ca} \text {, vit } \mathrm{A} \text { and } \\
\mathrm{Fe} \text { intake }\end{array}$ & $24 \mathrm{hr}$ recall \\
\hline $\begin{array}{l}\text { Hickson et al. } \\
(1986)\end{array}$ & $\begin{array}{r}22 \text { female basketball } \\
\text { gymnastics }\end{array}$ & & & $\begin{array}{l}\text { Mean intakes: } \\
69 \% \text { RDA vit } \mathrm{B}_{6} \\
57 \% \text { RDA for } \mathrm{Fe} \\
68 \% \text { RDA for } \mathrm{Mg} \\
55 \% \text { RDA for } \mathrm{Zn}\end{array}$ & $24 \mathrm{hr}$ recall \\
\hline
\end{tabular}


It is apparent that athletes may benefit from nutrition education during their school years. Nutrition intervention may help athletes improve their dietary habits with a positive effect on athletic performance and a decreased risk of future health problems. The short term goal is to increase the athlete's nutrition knowledge, while the long term goal is to promote good health by establishing appropriate food behaviors that continue throughout life.

\section{Efficacy of nutrition education:}

Nutrition education can make a difference. Welch et al. (8) reported an improvement in dietary quality for female college athletes receiving individual nutrition counseling. These athletes demonstrated a decrease in fat and cholesterol intakes and an increase in complex carbohydrate and fiber, compared to athletes who did not receive nutrition education.

There is limited research on different nutrition education approaches for college athletes. In a study by Franke (35), a significant knowledge gain was reported when comparing pre- and post-test questionnaire scores of female athletes receiving nutrition education to scores of those of the controls. In this study, all methods of nutrition education which included individual counseling, small group discussion and large group lecture, appeared equally successful in terms of both nutrition knowledge gain and dietary practice change. A need for nutrition intervention, regardless of the method used, is recognized $(2,6)$. 
A different nutrition education intervention was described by Updegrove and Johnson (36). Table tents presenting sports nutrition facts at the training table proved to be successful. Sixty three percent of the athletes surveyed agreed that the information presented was useful and $53 \%$ agreed that the information was new to them. However, knowledge gains could not be assessed as no experimental pre- and post-test design was followed.

Nutrition is one of the most neglected areas in sports medicine (37). Registered dietitians, the nutrition experts, are essential members of the sports medicine team. Their professional intervention includes nutrition education for athletes, coaches, trainers and team physicians, individual counseling for athletes, and/or the establishment of a healthy training table $(13,34,38)$. Not only athletes, but coaches and trainers, need and want correct nutrition information $(2,7,11,13-15,34,38-39)$.

The purpose of this study was to investigate the effect of nutrition education on the nutrition knowledge of both college male and female athletes. 


\section{METHODS AND PROCEDURES}

\section{Setting:}

The University of Miami, founded in 1926, is located in Coral Gables, Florida (40). The University of Miami is a member of the National Collegiate Athletic Association (NCAA), one of the two largest athletic organizations that administer intercollegiate sports programs at colleges and universities in the United States (40-41).

For the Fall 1990, the University's athletic department reported approximately 400 athletes participating on eight Division I sports: football, baseball, basketball (male and female), golf (male and female), tennis (male and female), swimming/diving (male and female), track/cross country (male and female), and cheerleading (male and female). Of these athletes, $77 \%$ were male and $23 \%$ were female.

\section{Subjects:}

The sample for this study was drawn from the total population of the University of Miami male football and female basketball players participating in the 1990-1991 season. 


\section{Instruments:}

1) Nutrition knowledge measurement

The Nutrition Achievement Test 4 (NAT 4) was selected as the instrument used to measure nutrition knowledge. This test was developed by the National Dairy Council and the Office of Evaluation Research at the University of Illinois in Chicago (24).

The test has 47 questions and was developed especially for students in grades 7 through 12 but may also be used with adults. The content validity was established by nutrition and education specialists. Reliability was 0.89 for grades $7-8$, and 0.88 for grades 9-10 (24).

The NAT 4 may be used to evaluate nutrition education needs in a particular school or to evaluate the effectiveness of a specific nutrition education program. Topics covered include: nutrition, nutrients, food handling, life cycle, social and psychological needs, food technology and nutrition and society.

Because of the broad nutrition concepts included in the NAT 4, questions were selected by the researcher to accommodate information targeted to athletic activities. Twenty-eight of the total 47 questions on the NAT 4 were included (Appendix A). The total number of questions by area for the NAT 4 and for this study's version are specified on Table 2 (24). 
Table 2. Nutrition Achievement Test: areas and number of questions covered.

\begin{tabular}{|c|c|c|c|}
\hline & \multirow{2}{*}{ AREA } & \multicolumn{2}{|c|}{ Number of questions } \\
\hline & & NAT 4 & Modified Version \\
\hline 1. & Nutrition & 12 & 8 \\
\hline 2. & Nutrients & 4 & 4 \\
\hline 3. & Food handling & 5 & 2 \\
\hline 4. & Life cycle & 6 & 2 \\
\hline 5. & $\begin{array}{l}\text { Social/psychological } \\
\text { aspects of food }\end{array}$ & 10 & 5 \\
\hline 6. & Food technology & 7 & 5 \\
\hline 7. & Nutrition and society & 3 & 2 \\
\hline & TOTAL & 47 & 28 \\
\hline
\end{tabular}

\section{2) Anthropometrics}

Height: Heights were obtained using a measuring tape attached to a vertical flat surface. Subjects first removed shoes and any other accessories that could affect the measuring. Subjects were instructed to stand with heels, buttocks, shoulders and head touching the vertical surface, to place heels together, and to hold head straight, looking straight ahead. A 90 degree ruler was then positioned on the subject's head and the measurement read.

Weight: Weights were obtained using a platform scale, Toledo Model 2181, calibrated 0-500 lbs. (Toledo Corp.). The scale was checked to be at zero before and after each measurement. Subjects were weighed wearing light clothing, with no shoes.

Body composition: Body composition was assessed with skinfold measurements. An 
electronic caliper, Skyndex System I (Caldwell, Justiss and Comp, Inc.) was the measuring instrument. Readings were obtained from three sites which varied with gender: chest, abdomen and thigh for male athletes; triceps, thigh and suprailiac for female athletes. All of these measurements were taken on the right side of the body (42).

\section{3) Dietary intake}

A review of the literature indicates the self-reported dietary intakes to be relatively accurate and the three-day diet record to provide a reasonable estimate of the general quality of the diet (43-45). The self-reported three-day diet record was estimated to be a reliable tool to assess the athlete's nutritional adequacy and an appropriate instrument for use in this study (Appendix B).

\section{4) Lesson plans}

Nutrition education was offered by six weekly sessions (Appendix C). Each lesson, 20-25 minutes long, was developed by the researcher based upon topics selected from the NAT 4 and suggested topics reported in the literature $(6,10)$. Topics covered included:

1. General nutrition principles for athletes.

2. Pre-game meals and fluid replacement.

3. Fast foods.

4. Healthy food choices: nutrition labeling.

5. Nutritional ergogenic aids.

6. Weight control and body composition.

Lectures, discussion and demonstrations were the means used to provide nutrition education. Food models, charts, videos and handouts were used to enhance learning and 
to hold the interest of the athletes. Participation in group discussion and questions/answers sessions was encouraged.

\section{Experimental design:}

The design followed was the pre-test/post-test control group design (Table 3). This design was selected because of the involvement of two similar groups, experimental and control, one of which received a treatment or intervention (46). Both groups were administered a pre-test and a post-test on the nutrition knowledge. To determine effectiveness of nutrition intervention, post-test scores were compared to pre-test scores.

Pre-test treatment interaction, which may affect external validity, is a potential threat identified with this design. However, it is believed not to be a major threat because of the duration of the study ( 3 months).

\section{Procedure:}

The sample for this study was one of convenience. Criteria for assigning athletes to the experimental and control groups was based upon the athletic trainer's judgement. The experimental group from the male athletes consisted of freshmen and new players; the control group was composed of sophomore and junior players. For female athletes, the experimental group consisted of basketball players and the control group of members of the crew team.

Anthropometric measurements included weight, height and percentage of body fat. These measurements were assessed as part of the pre-season physical examination and done by the assistant athletic trainer. 
Table 3. Experimental design: timetable.

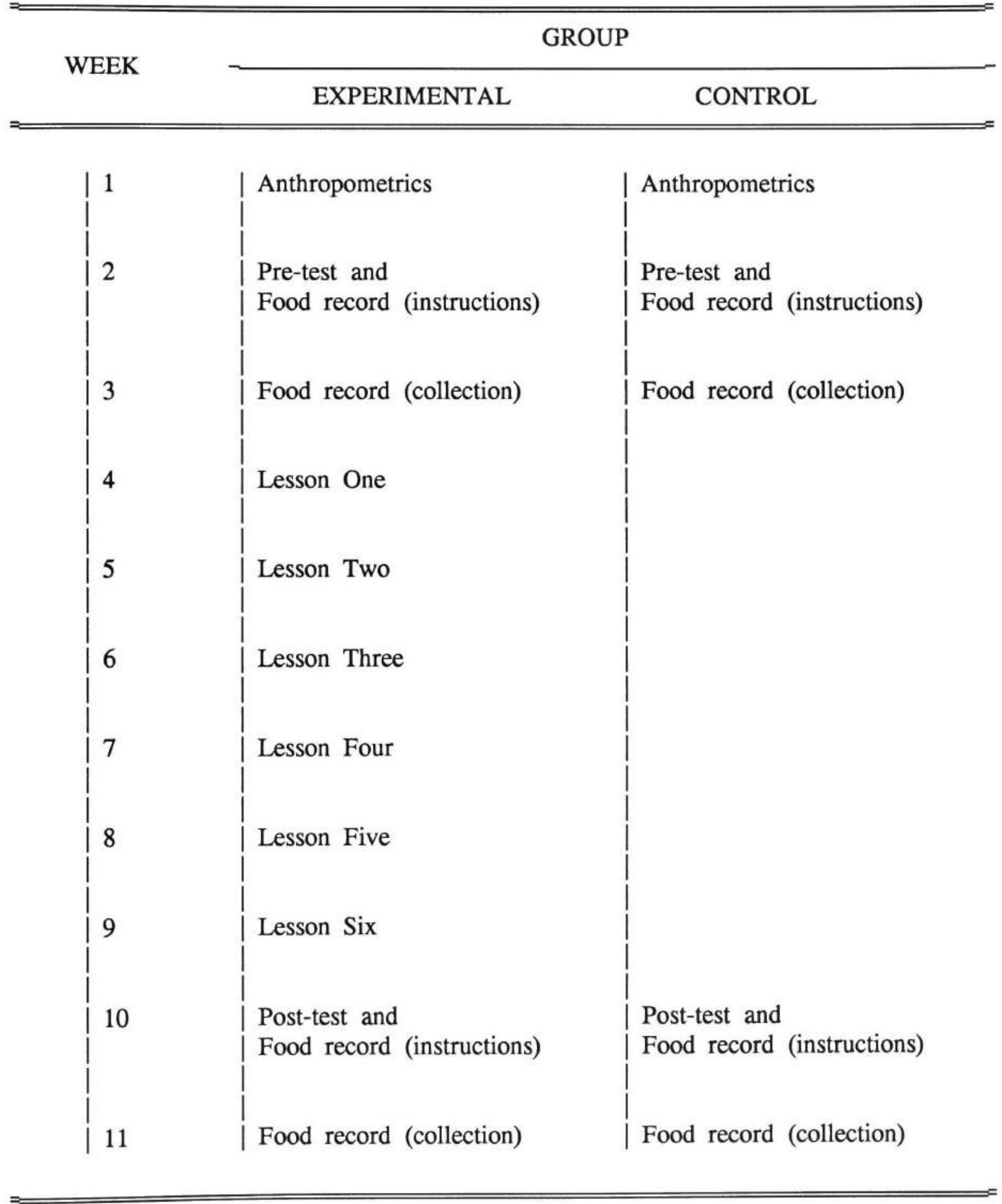


Both groups, experimental and control, were to complete the NAT 4 and a three-day record one week prior the beginning of the football season and again at the end of the nutrition education (three months later). Instructions on how to keep a diet record were given to the athletes and trainers (Appendix B). Household measuring cups and spoons; bowls, cups and plates from the training table; and food models were used to aid players in estimating portion sizes.

Members of the experimental groups received nutrition intervention via lectures on nutrition principles for athletes. Six lessons, each approximately 20 to 25 minutes long, were presented in the Athletic Center Conference Room. Attendance was verified by an athletic trainer who was present in all sessions. The control groups received no nutrition education during the study. Following the intervention program however, nutrition education was made available to control groups on both teams.

\section{Data analysis:}

Diet records, from both female and male athletes, were analyzed for nutrient composition by the microcomputer software program, Dietary Intake Analysis, Computrition Inc. (47). This program uses nutrient values from the revised U.S.D.A.Handbook 8 Series, U.S.D.A.Handbook 456, and data on brand-name items from manufacturers' published data (25). Nutrient composition included:
a) Kilocalorie intake.
b) Protein intake $(\mathrm{g})$.
c) Fat intake (g). 

d) Carbohydrate intake (g).
e) Percentage of total kilocalories from carbohydrates, protein and fat.
f) Fiber intake (g).
g) Cholesterol intake (mg).
h) Micronutrients: iron (mg), sodium (mg), calcium (mg), phosphorus (mg), vitamin A (IU), thiamine (mg), riboflavin (mg), vitamin C (mg), potassium (mg), zinc (mg), niacin (mg), vitamin $\mathrm{B}_{6}(\mathrm{mcg})$, vitamin $\mathrm{B}_{12}(\mathrm{mcg})$, and folacin $(\mathrm{mcg})$.

Vitamin, mineral and other supplements were noted but not included in the diet analysis because of the experimental objective of assessing the adequacy of food sources.

Nutrient intakes for athletes in this study were compared to recommendations (ESAI: Estimated Safe and Adequate Intake) and the 1989 Recommended Dietary Allowances (RDA) (49). Two-thirds of the recommendation or allowances was the criteria for identification of "poor" or "adequate" nutrient intake, a common standard as reported in the literature $(2,8,14,48)$.

Nutrition knowledge scores were assessed for the 28 questions selected from the NAT 4. Pre-test and post-test scores of each group, experimental and control, were compared to identify significant changes.

Gain scores, or differences, for each subject were computed (post-test minus pre-test score). The average gain score of the experimental group was compared to that of the control group.

A probability level of $<0.05$ was set as the criterion for statistical significance. 


\section{CHAPTER FOUR}

\section{RESULTS AND DISCUSSION}

\section{Anthropometric measurements:}

This study was initially composed of 24 female and 46 male athletes. Age of the females ranged from 18 to 22 years old, weight from 115 to 202 pounds, height from 59 to 74.5 inches and percentage of body fat from 12.2 to $29 \%$. For male athletes, age ranged between 17 to 23 years old, weight 156 to 318 pounds, height from 58.25 to 80.5 inches, and percentage of body fat between 3.8 and $19.79 \%$ (Table 4).

These measurements were taken at the beginning of the study as part of the preseason physical examination. The same assistant athletic trainer was responsible for measuring all athletes participating in the study.

\section{Nutrition knowledge level:}

Female athletes: pre-test values

Twenty four female players completed the nutrition knowledge test at the beginning of the study. The experimental group consisted of 13 players and the control of 11 players. Mean score for the team was $23.79 \pm 5.2$, with a range in scores of $7-28$ points. The experimental group $(n=13)$ had a mean score of $21.76 \pm 6.41$ (range 7-28), compared to the control group $(n=11)$ which had a mean score of $26.18 \pm 1.16$ (range 24-28). 
Table 4. Anthropometric measurements for female and male athletes at the beginning of the season. (Mean \pm standard deviation)

\begin{tabular}{cccc}
\hline $\begin{array}{c}\text { AGE } \\
\text { (years) }\end{array}$ & $\begin{array}{c}\text { HEIGHT } \\
\text { (in) }\end{array}$ & $\begin{array}{c}\text { WEIGHT } \\
\text { (lbs) }\end{array}$ & $\begin{array}{c}\% \text { BODY } \\
\text { FAT }\end{array}$ \\
\hline
\end{tabular}

Female athletes

Experimental

$\begin{array}{lllll}\mathrm{n}=13 & 19.20 \pm 1.00 & 69.16 \pm 2.33 & 163.53 \pm 22.82 & 18.86 \pm 4.23 \\ \text { (range) } & (18-22) & (67-74.5) & (142-202) & (12.2-29.0)\end{array}$

Control

$\mathrm{n}=11$

$19.60 \pm 0.67$

$66.27 \pm 3.85$

$146.13 \pm 17.80$

$17.85 \pm 2.06$

(range)

$(19-21)$

$(59-70.5)$

(115 - 172)

$(13.7-19.6)$

Team

$\mathrm{n}=24$

$19.40 \pm 0.93$

$67.78 \pm 3.41$ I

$154.80 \pm 22.00$

$18.40 \pm 3.39$

* $\mathrm{n}=12$

I $n=23$

Male athletes

Experimental

$\mathrm{n}=17$

$18.23 \pm 0.66$

$74.88 \pm 2.57$

$228.94 \pm 44.22$

$9.83 \pm 4.89$ *

(range)

(17 - 19)

(70 - 80.5)

(156 - 318)

$(3.8-17.4)$

Control

$\mathrm{n}=29$

$19.34 \pm 1.00$

$72.07 \pm 3.82$

(58.2 - 78.5)

$209.46 \pm 36.95$

(162.5 - 285)

$10.84 \pm 4.39$ I

(range)

(18 - 23)

$18.90 \pm 1.00$

$73.11 \pm 3.65$

$216.60 \pm 40.40$

$10.42 \pm 4.39$ s

Team
$\mathrm{n}=46$

* $\mathrm{n}=10$

I $\mathrm{n}=14$

$\S \mathrm{n}=24$ 
A two sample t-test indicated a significant difference $(\mathrm{t}=2.43, \mathrm{p}<0.03)$ between pretest scores between the experimental and control groups with the control group scoring higher on the average.

Male athletes: pre-test values

A total of 46 football players completed the nutrition knowledge test at the beginning of the study. Of these, 16 players comprised the experimental group and 30 the control group.

The mean test score for male athletes was $16.93 \pm 6.73$ of a possible 28 points. The lowest score was four points and the highest was 28 points. The mean score for the experimental group $(n=16)$ was $15.25 \pm 5.26$ (range 6-24), compared to the control group $(n=30)$ which had a mean score of $17.76 \pm 7.34$ (range $4-28)$.

A two sample t-test was performed to assess pretest scores between the experimental and control group. No significant difference was found $(\mathrm{t}=-1.15, \mathrm{p}<0.25)$.

Pre-test values: a comparison between female and male athletes

A two sample t-test was performed to compare pre-test values for the nutrition knowledge test between female and male athletes. Female athletes had a mean score of $23.79 \pm 5.20$ while male athletes of $16.93 \pm 0.99$. There was a significant difference between these scores $(\mathrm{t}=4.35, \mathrm{p}<0.01)$ with female athletes scoring almost seven points higher. 


\section{Pre and post-test comparison}

To assess the effect of nutrition education on the nutrition knowledge of athletes, pre-test and post-test were evaluated for both female and male athletes. Only those athletes who completed both tests were included: 16 females and 23 males.

Female athletes: comparisons within groups

A t-test was used to determine if there was a significant difference in mean gain score for the experimental and control groups separately. Mean test gain scores (post-test minus pre-test) revealed a significant difference for the experimental group $(n=12, t=2.52, p<0.01)$ and no significant difference for the control group $(n=4, t=1.00, p<0.39)$ (Table 5). Female athletes: a comparison between groups

There was a significant difference $(t=2.06, \mathrm{p}<0.03)$ between the experimental group $($ mean $=1.83)$ and control group $($ mean $=0.25)$ for the mean gain scores on the nutrition test using a two-sample t-test (Table 5).

Pre-test means for both groups were not significantly different $(t=-2.05, \mathrm{p}<0.06)$ but approached statistical significance (Table 5). Therefore, analysis of covariance (ANCOVA) was also performed to adjust for the pre-tests on the post-test scores. No significant difference between experimental and control groups was found in the adjusted post-test means $(p<0.66)($ Table 6$)$. This may be partially explained by the small sample and uneven number of subjects ( $n=12$ for the experimental group, $n=4$ for the control group). 
Table 5. Mean pre-test and post-test scores and mean differences for females athletes.

$=$\begin{tabular}{lllll}
\hline PRE & POST & DIFF & $\mathrm{t}$ & $\mathrm{p}$ VALUE
\end{tabular}

$\underline{\text { Female athletes }}$

Experimental

$(n=12)$

23.00

24.80

1.83

2.52

0.01 *

$(n-12)$

Control

$(n=4)$

26.00

26.25

0.25

1.00

$0.39 \mathrm{NS}$

\section{I}

Comparison within groups:

* Significant at the $\mathrm{p}<0.02$ level

Comparison between groups:

I Significant at the $\mathrm{p}<0.03$ level

NS Not significant at the $\mathrm{p}<0.05$ level

Table 6. Mean pre-test, post-test, and adjusted post-test scores for female athletes. (Mean \pm standard deviation)

\begin{tabular}{lccc}
\hline \hline & PRE-TEST & $\begin{array}{c}\text { POST-TEST } \\
\text { (unadjusted) }\end{array}$ & $\begin{array}{l}\text { POST-TEST } \\
\text { (adjusted) }\end{array}$ \\
$=\overline{\text { Experimental }}(\mathrm{n}=12)$ & $23.00 \pm 4.84$ & $24.83 \pm 3.37$ & 25.29 \\
& $\mathrm{NS}$ & $\mathrm{NS}$ \\
$\begin{array}{l}\text { Control } \\
(\mathrm{n}=4)\end{array}$ & $26.00 \pm 0.81$ & $26.25 \pm 0.95$ & 24.87 \\
$=$ & & & \\
\hline \hline
\end{tabular}

NS Not significant at the $\mathrm{p}<0.05$ level 
Male athletes: comparisons within groups

A t-test was used to determine if there was a significant difference on the mean gain score for the experimental and control groups separately. The mean test gain score revealed no significant difference, post-test minus pre-test, for the experimental group ( $n=13, t=-1.94$, $\mathrm{p}<0.92)$ nor the control group $(\mathrm{n}=10, \mathrm{t}=-0.32, \mathrm{p}<0.75)$. No improvement on test scores was indicated for either group. Both showed a negative trend $(-3.15$ and -0.50$)$ (Table 7). Male athletes: a comparison between groups

A two-sample t-test on the mean gain test scores (post-test minus pre-test) for the experimental and control groups showed no significant difference $(t=-1.15, \mathrm{p}<0.13)$. No significant difference was found when comparing pre-test scores for both groups $(t=-0.43$, $\mathrm{p}<0.67)$ (Table 7).

Table 7. Mean pre-test and post-test scores and mean differences for male athletes.

$=$\begin{tabular}{lllll}
\hline PRE & POST & DIFF & $\mathrm{t}$ & $\mathrm{p}$-VALUE \\
\hline
\end{tabular}

Male athletes

$\begin{array}{lccccc}\begin{array}{l}\text { Experimental } \\ (\mathrm{n}=13)\end{array} & 16.31 & 13.15 & -3.15 & -1.95 & 0.924 \text { NS } \\ & & & \text { NS } & & \\ \begin{array}{l}\text { Control } \\ (n=10)\end{array} & 17.40 & 16.9 & -0.50 & -0.32 & 0.754 \text { NS }\end{array}$

NS Not significant at the $\mathrm{p}<0.05$ level 


\section{Dietary intake:}

Female athletes: pre-test values

Three day diet records were collected for 19 female athletes. Energy and 19 nutrients were analyzed by the Computrition software program (Table 8).

Comparing intakes to recommendations (ESAI) and RDAs, the mean protein intake was significantly higher $(\mathrm{p}<0.05)$ while carbohydrates, fiber, cholesterol, iron, calcium, phosphorus, zinc and vitamin $B_{6}$ were significantly lower $(p<0.05)$. Considering $2 / 3$ RDA or ESAI as criteria for nutrient adequacy, fiber, calcium and zinc intakes were estimated to be poor.

Female athletes: a comparison between groups

Pre-test diet records were compared, experimental $(n=11)$ and control $(n=8)$ groups. No significant mean differences were found for energy and 19 nutrients. The only significant difference found was in the mean percentage of kilocalories from protein, which was higher in the experimental group, $16 \%$ compared to $12 \%$ for the control group (Table 9).

Male athletes: pre-test values

Thirteen dietary records were assessed for male athletes (Table 8). According to recommendations (ESAI) and RDAs, protein, cholesterol, iron, sodium, phosphorus, thiamin, vitamin $\mathrm{C}$, potassium and niacin were significantly higher $(\mathrm{p}<0.05)$; fiber and calcium were significantly lower $(\mathrm{p}<0.05)$. Fiber intake was considered to be poor (less than $2 / 3$ ESAI). 
Table 8. Pre-test dietary intake for female $(n=19)$ and male $(n=13)$ athletes.

\begin{tabular}{|c|c|c|c|c|}
\hline \multirow[t]{2}{*}{ NUTRIENT } & \multicolumn{2}{|c|}{ MEAN INTAKE } & \multicolumn{2}{|c|}{ \% RECOMMENDATION } \\
\hline & FEMALE & MALE & FEMALE & MALE \\
\hline Energy (kcal) & $1876.1 \pm 741.9$ & $2992.2 \pm 925.9$ & $85 \%$ & $101 \%$ \\
\hline Protein (g) & $66.3 \pm 25.7$ & $121.9 \pm 39.0$ & $145 \%$ & $208 \%$ \\
\hline Fat $(\mathrm{g})$ & $71.8 \pm 39.8$ & $116.7 \pm 53.9$ & $98 \%$ & $119 \%$ \\
\hline Carbohydrates (g) & $239.8 \pm 93.9$ & $362.7 \pm 132.0$ & $79 \%$ & $89 \%$ \\
\hline Fiber (g) & $10.1 \pm 4.9 \Rightarrow$ & $8.7 \pm 4.7$ & $51 \%$ ก & $44 \%$ ก \\
\hline Cholesterol (mg) & $227.7 \pm 125.7$ & $543.0 \pm 305.9$ & $76 \%$ & $181 \%$ \\
\hline Iron (mg) & $10.3 \pm 3.3$ & $16.3 \pm 4.6$ & $69 \%$ & $150 \%$ \\
\hline Sodium (mg) & $2726.8 \pm 1172$ & $4169.1 \pm 1611$ & $114 \%$ & $174 \%$ \\
\hline Calcium (mg) & $739.2 \pm 436.7$ & $829.1 \pm 326.6$ & $62 \% \pi$ & $69 \%$ \\
\hline Phosphorus (mg) & $993.5 \pm 407.3$ & $1544.4 \pm 404.1$ & $83 \%$ & $129 \%$ \\
\hline Vitamin A (IU) & $5247.0 \pm 3824$ & $5698.9 \pm 3593$ & $131 \%$ & $114 \%$ \\
\hline Thiamin (mg) & $1.1 \pm 0.5$ & $2.1 \pm 0.6$ & $102 \%$ & $137 \%$ \\
\hline Riboflavin (mg) & $1.3 \pm 0.7$ & $1.9 \pm 0.6$ & $99 \%$ & $110 \%$ \\
\hline Vitamin C (mg) & $91.6 \pm 70.0$ & $233.5 \pm 209.9$ & $153 \%$ & $389 \%$ \\
\hline Potassium (mg) & $2055.5 \pm 842.0$ & $3262.9 \pm 973.7$ & $103 \%$ & $163 \%$ \\
\hline Zinc (mg) & $7.5 \pm 3.4$ & $12.2 \pm 4.7$ & $60 \%$ ก & $82 \%$ \\
\hline Niacin (mg) & $17.1 \pm 6.4$ & $29.9 \pm 9.9$ & $114 \%$ & $153 \%$ \\
\hline Vitamin $\mathrm{B}_{6}(\mathrm{mcg})$ & $1231.3 \pm 588.8$ & $1854.1 \pm 917.4$ & $78 \%$ & $93 \%$ \\
\hline Vitamin $\mathrm{B}_{12}(\mathrm{mcg})$ & $2.3 \pm 1.5$ & $5.0 \pm 1.9$ & $114 \%$ & $252 \%$ \\
\hline Folacin (mcg) & $196.7 \pm 116.6$ & $267.6 \pm 134.9$ & $109 \%$ & $134 \%$ \\
\hline
\end{tabular}

* Significant at the $\mathrm{p}<0.05$ level

I Less than $2 / 3$ RDA

Recommendations (ESAI):

Fiber: $20 \mathrm{~g}$

Cholesterol: $300 \mathrm{mg}(\max )$

Sodium: $2,400 \mathrm{mg}(\max )$

Energy: $30-35 \mathrm{kcal} / \mathrm{kg}$ body weight 
Male athletes: a comparison between groups

No significant differences were found for energy, 19 nutrients or distribution of energy nutrients when comparing the mean pre-test diet intake, experimental $(n=8)$ and control $(n=5)$ groups (Table 9).

Table 9. Pre-test energy nutrients distribution.

\begin{tabular}{lcc}
$\%$ Kcal & $\%$ Kcal & $\%$ Kcal \\
Protein & Fat & Carbohydrates \\
\hline \hline
\end{tabular}

Basketball

Experimental

$16.2 \%$

$30.3 \%$

$53.4 \%$

$(n=11)$

*

Control

$12.6 \%$

$36.9 \%$

$50.5 \%$

$(\mathrm{n}=8)$

Football

Experimental

$16.8 \%$

$35.2 \%$

$48.0 \%$

$(n=8)$

Control

$16.4 \%$

$33.9 \%$

$49.6 \%$

$(\mathrm{n}=5)$

* Significant at the $\mathrm{p}<0.02$ level 
Pre and post-test comparison

To determine the effect of nutrition education on nutrient intake, pre-test and posttest diet records were compared. Only those athletes who completed both records were included: five female and five males, all members of the experimental groups.

Female athletes: a comparison within group

Mean nutrient intakes were not significantly different from pre-test to post-test, with the exception of folacin $(n=5, t=5.05, p<0.01)$. The mean folacin intake was significantly higher on the post-treatment diet record (Table 10).

Male athletes: a comparison within group

None of the nutrients analyzed had significantly different means from pre-test to posttest (Table 11). 
Table 10. Pre-test and post-test dietary intake for female athletes $(n=5)$.

\begin{tabular}{||l|c|c|c||}
\hline \multicolumn{1}{|c|}{ NUTRIENT } & PRE-TEST & POST-TEST & SIGNIFICANCE \\
\hline Energy (kcal) & $1508.0 \pm 740.2$ & $1649.2 \pm 283.5$ & NS \\
\hline Protein (g) & $59.6 \pm 27.8$ & $56.9 \pm 12.2$ & NS \\
\hline Fat (g) & $46.1 \pm 32.2$ & $55.2 \pm 25.4$ & NS \\
\hline Carbohydrates (g) & $214.9 \pm 99.9$ & $241.0 \pm 34.2$ & NS \\
\hline Fiber (g) & $9.3 \pm 4.6$ & $12.9 \pm 6.5$ & NS \\
\hline Cholesterol (mg) & $161.4 \pm 106.5$ & $198.4 \pm 163.6$ & NS \\
\hline Iron (mg) & $10.5 \pm 3.7$ & $15.7 \pm 6.6$ & NS \\
\hline Sodium (mg) & $2470.2 \pm 1213.0$ & $2586.4 \pm 583.0$ & NS \\
\hline Calcium (mg) & $585.6 \pm 240.5$ & $705.2 \pm 249.8$ & NS \\
\hline Phosphorus (mg) & $807.8 \pm 254.6$ & $1087.8 \pm 401.4$ & NS \\
\hline Vitamin A (IU) & $4074.2 \pm 2615.0$ & $10123.8 \pm 10034.0$ & NS \\
\hline Thiamin (mg) & $1.1 \pm 0.4$ & $1.6 \pm 0.6$ & NS \\
\hline Riboflavin (mg) & $1.2 \pm 0.5$ & $1.8 \pm 0.5$ & NS \\
\hline Vitamin C (mg) & $129.8 \pm 49.9$ & $67.8 \pm 46.4$ & NS \\
\hline Potassium (mg) & $1832.0 \pm 498.6$ & $2264.2 \pm 494.5$ & NS \\
\hline Zinc (mg) & $7.2 \pm 3.1$ & $10.2 \pm 5.0$ & NS \\
\hline Niacin (mg) & $16.4 \pm 5.9$ & $19.5 \pm 5.8$ & NS \\
\hline Vitamin B $(\mathrm{mcg})$ & $1354.6 \pm 681.4$ & $1954.4 \pm 857.6$ & NS \\
\hline Vitamin B $(\mathrm{mcg})$ & $1.9 \pm 1.2$ & $4.1 \pm 1.7$ & NS \\
\hline Folacin (mcg) & $169.8 \pm 59.6$ & $294.0 \pm 107.5$ & \\
\hline
\end{tabular}

NS Not significant

* Significant at the $\mathrm{p}<0.05$ 
Table 11. Pre-test and post-test dietary intake for male athletes $(n=5)$.

\begin{tabular}{||l|c|c|c||}
\hline \multicolumn{1}{|c|}{ NUTRIENT } & PRE-TEST & POST-TEST & SIGNIFICANCE \\
\hline Energy (kcal) & $3073.2 \pm 909.8$ & $2499.8 \pm 707.5$ & NS \\
\hline Protein (g) & $117.2 \pm 22.8$ & $98.2 \pm 27.7$ & NS \\
\hline Fat (g) & $103.1 \pm 33.9$ & $80.1 \pm 26.2$ & NS \\
\hline Carbohydrates (g) & $416.1 \pm 166.2$ & $343.3 \pm 141.4$ & NS \\
\hline Fiber (g) & $7.1 \pm 5.8$ & $10.9 \pm 10.9$ & NS \\
\hline Cholesterol (mg) & $643.6 \pm 280.5$ & $670.4 \pm 227.4$ & NS \\
\hline Iron (mg) & $15.7 \pm 4.9$ & $14.8 \pm 2.4$ & NS \\
\hline Sodium (mg) & $4410.4 \pm 1187.3$ & $2992.8 \pm 1591.6$ & NS \\
\hline Calcium (mg) & $763.4 \pm 339.0$ & $776.6 \pm 468.3$ & NS \\
\hline Phosphorus (mg) & $1470.8 \pm 247.5$ & $1397.6 \pm 295.4$ & NS \\
\hline Vitamin A (IU) & $5274.4 \pm 5311.5$ & $5369.8 \pm 5683.6$ & NS \\
\hline Thiamin (mg) & $2.2 \pm 0.9$ & $1.6 \pm 0.6$ & NS \\
\hline Riboflavin (mg) & $2.0 \pm 0.5$ & $1.7 \pm 0.6$ & NS \\
\hline Vitamin C (mg) & $342.2 \pm 309.1$ & $258.8 \pm 262.8$ & NS \\
\hline Potassium (mg) & $2876.2 \pm 648.2$ & $2398.6 \pm 719.3$ & NS \\
\hline Zinc (mg) & $12.4 \pm 3.9$ & $13.8 \pm 2.5$ & NS \\
\hline Niacin (mg) & $29.4 \pm 7.2$ & $21.8 \pm 8.2$ & NS \\
\hline Vitamin B $_{6}(\mathrm{mcg})$ & $1664.2 \pm 1042.1$ & $1527.2 \pm 364.3$ & NS \\
\hline Vitamin B $(\mathrm{mcg})$ & $5.3 \pm 0.9$ & $6.5 \pm 2.7$ & NS \\
\hline Folacin (mcg) & $256.6 \pm 179.4$ & $289.4 \pm 185.1$ & \\
\hline
\end{tabular}

NS Not significant 


\section{DISCUSSION}

\section{Data collection:}

A major limitation for this study was data collection procedures. As mentioned, the experimenter had limited access to the athletes; all contacts were made through the Head Athletic Trainer.

Even though assistants were instructed on the method to use for completing diet records and for administration of the nutrition test, the experimenter was not present during data collection (except for the pre-test given to male athletes). This may have affected the findings of this study.

\section{Anthropometrics:}

Physical measurements were taken by only one athletic trainer as part of the preseason examination. This positively affects the reliability of the measurements as there was consistency of the method. However, data was not completed for all athletes (see Table 4) and a follow up at the end of the study was not feasible.

Anthropometric measurements for athletes have been discussed. The Metropolitan Life Insurance Company Standards, published in 1959 and updated in 1983, are the most commonly used to determine ideal or desirable body weight. However, these tables have limited application for athletes because of their different body composition when compared to that of the general population (44). 
Body composition for athletes varies by sport and measurements are usually compared to existing ranges rather than ideal values. Marcus (44) reports body composition ranges of $20.8-26.9 \%$ body fat for female basketball athletes and $9.4-19.1 \%$ body fat for male football athletes.

Findings of this study show female athletes with a range of $12.2-29 \%$ body fat and male athletes with $3.8-19.8 \%$. Lower range percentages differ from those reported by Marcus (44). Although a low body fat is desirable for better performance, recommendation should consider individual's performance level, age and sport.

\section{Sample size:}

Sample size for this study was relatively small and findings are specifically addressed to this population. Extrapolation to the general population is not applicable.

\section{Nutrition knowledge:}

Misconceptions: female and male athletes

Several misconceptions were identified on the pre-test using the responses of 24 female and 46 male athletes. These misconceptions are presented on Table 12 .

\section{Dietary intake:}

\section{Female athletes:}

Pre-test dietary intake for 19 female athletes indicated a poor intake of fiber (51\% ESAI), calcium (62\% RDA) and zinc (60\% RDA). These findings are in accordance to 
Table 12. Misconceptions identified upon the responses of female $(n=24)$ and male $(n=46)$ athletes.

MISCONCEPTION
\% RESPONSE

FEMALE

MALE

"Someone who's trying to lose weight should avoid going 37

out with friends when they go to a fast food restaurant."

"Alcohol increases the body's absorption of nutrients."

"Green beans are a better source of protein than eggs."

"Candy bars have a lot of sugar which eats up energy."

12

12

"Ads for food products educate the public about nutrition."

12

12

"Vitamins and minerals have little to do with athletic performance."

"Supplements are the best way for athletes to get vitamins and minerals."

"The best information source for the nutrient content of a fabricated food is a "taste test"."

"Candy bars provide calories, not energy."

"The most important factor when planning a diet for athletes is to add large doses of vitamins to the diet."

"Television ads are better sources of the nutrition value of food than nutrition labels."

"A food would be more nutritious than another if it has fewer calories rather than more important nutrients."

"Total caloric needs are determined by your doctor rather than by basal metabolism and physical activity."

"Drinking eight glasses of water each day and eating only fruits and vegetables is a safer way to lose weight than reducing caloric intake and increasing physical activity." 
those reported by Perron and Endres (12) (64\% RDA for calcium) Short and Short (2) (poor calcium intake, although not defined), and Hickson et al. (17) (55\% for zinc). Iron intake assessed for this study was $69 \% \mathrm{RDA}$, close to that reported by the same authors (60\% RDA, "poor" iron intake and 57\% RDA, respectively).

Comparing pre-test intakes between experimental and control groups, there was no significant difference except for percentage of kilocalories from protein (Table 9). Distribution of energy nutrients for the experimental group were $16.2 \%$ PRO, $30.3 \%$ FAT and $53.4 \% \mathrm{CHO}$, while for the control group were $12.6 \% \mathrm{PRO}, 36.9 \%$ FAT and $50.5 \%$ CHO. These values were not significantly different from the recommended percentage for calorie distribution $(15 \%, 30 \%$ and $55 \%$ respectively).

Male athletes:

Male athletes $(n=13)$ reported poor fiber intake $(44 \%$ ESAI). Other nutrients were above 2/3 RDA or ESAI; protein, cholesterol, iron, sodium, phosphorus, thiamin, vitamin $\mathrm{C}$, potassium and niacin were considered to be significantly higher than corresponding RDA or ESAI. Even so, these findings were below those reported by Short and Short (2) for a similar population (See Table 1).

Energy nutrient distribution for the experimental (16.8\% PRO, 35.2\% FAT and 48\% CHO) and control groups (16.4\% PRO, 33.9\% FAT and 49.6\% CHO) were not significantly different at the $\mathrm{p}<0.05$ level. Comparing these values to those recommended $(15 \% \mathrm{PRO}$, $30 \%$ FAT and $55 \% \mathrm{CHO}$ ), significant differences were not noted. 
Discussion on the dietary intake measuring instrument:

Most methods of dietary assessment used with athletes have relied upon the subject's willingness to record or recall one or more days of food intake $(2,8,12,14,17)$. Eck et al. (13) suggested that direct observation produced a more reliable estimate of kinds and amounts of food eaten by college football athletes in a study they completed. However, only foods served on a training table and under the supervision of the observers were recorded which excluded meals and snacks eaten away from the athletic cafeteria.

Woteki (43) affirms that the 24-hour recall and food record are limited on the subject's ability to remember and describe what is consumed. Frequently, a food record becomes a recall when the respondent fails to record what is eaten and relies on memory to complete the record. Accuracy depends on the respondents' ability to estimate portion sizes and/or their cooperation in recording foods consumed (44).

Reliability of diet records has been examined. The three-day diet record (record of food consumed for a three day period) has been reported to give a fair picture of intake as compared to the 24-hour food recall (44). The latter is considered to provide accurate and reproducible estimates of the mean intakes of population groups, but is less reliable for individual estimates of usual intake (43-44).

Criteria for nutritional adequacy of athletes' diets has been discussed. The RDAs were established for healthy people in the United States (48), and do not represent individual nutrient requirements. Furthermore, they have limited application for athletes since they are based on a reference man and woman with a different body composition and activity pattern (2). Given these limitations, the RDAs are still useful as a relative index 
of nutritional adequacy for athletes (2).

For the purposes of this study, it was estimated that the self-reported three-day diet record was an appropriate dietary intake instrument. RDAs and ESAIs (fiber, cholesterol, sodium, energy and energy nutrients caloric distribution) were selected as criteria for measuring adequacy of these athletes' diets. Two thirds of RDA or ESAI was the criteria for identification of "poor" or "adequate" nutrient intake.

\section{Implications:}

Female athletes:

Female athletes who received nutrition education showed a significant improvement on their post-test nutrition knowledge scores as compared to those of the pre-test. The control group did not show a significant improvement. Regarding dietary intake, there were no significant improvements in nutritional adequacy for the experimental group (except for folacin).

During the nutrition lectures, athletes demonstrated interest on the topics being presented. They participated by asking questions and sharing personal experiences. Even, at the end of the lectures, they remained in the room to discuss information with the researcher.

Male athletes:

Male athletes did not significantly improve their pre-test nutrition knowledge scores. The experimental and control groups both demonstrated lower post-test scores compared 
to pre-test scores, but were not significantly different from each other. No significant improvement for adequacy of the diet was noted either.

The participation of this group of football players during the lectures and willingness to complete the food records was poor. Few of them took part in the discussion with a genuine interest. It was noted, however, that specific topics such as body composition and nutrition myths were of the most concern, and that the use of audiovisual material (food models, videos and charts) slightly increased their attentiveness.

Looking at the results for the male athletes who completed the pretest $(n=46)$, the average score was $60 \%$, with a score range of $14 \%$ to $100 \%$. Reviewing their responses, several misconceptions were identified as mentioned earlier.

It is assumed that these misconceptions continued during the duration of this study. The experimental group did not improve their post-test scores, implying that the knowledge acquired during the nutrition intervention was not reflected on the post-test. 


\section{CHAPTER FIVE}

\section{CONCLUSIONS AND RECOMMENDATIONS}

\section{Conclusions:}

The purpose of this study was to investigate the effect of nutrition education on the nutrition knowledge of college male and female athletes. The main research hypothesis was that college athletes who received nutrition education would demonstrate a significant improvement in nutrition knowledge when test scores were compared to those who did not

receive nutrition education. This hypothesis was supported for female athletes but not for male athletes.

Female athletes in the experimental group demonstrated a significant improvement on test scores (post-test minus pre-test); no improvements were noted for the control group. When pre-test means for both groups were examined no significance was noted. No significant improvements on test scores for either the experimental or control group of male athletes were shown.

The second research hypothesis that college athletes who received nutrition education would show a significant improvement in nutritional adequacy of their diets was not supported for either female or male athletes. The only nutrient for which a significant improvement was noted was folacin for the experimental group of female athletes. 
The findings of this study indicate that nutrition education offered through small group lectures resulted in a significant improvement in the nutrition knowledge of college female athletes. No such improvement was noted for the group of male athletes. A different educational approach may be warranted for these male athletes.

\section{Recommendations:}

For further research regarding the effects of nutrition education on nutrition knowledge and/or adequacy of the diet of college athletes, it is recommended that the researchers be directly involved with the athletes. The experimenters need to coordinate research activities with coaches and trainers, and there should be agreement on research procedures and commitment from both parties. Athletes are engaged in strenuous physical and mental training besides their normal schoolwork, an extra activity such as nutrition intervention may add more stress and pressure. Nutrition intervention should be brief, interesting, practical and on-going.

It is also recommended that nutrition education be provided to only one group of athletes at a time: female or male. It appeared that the nutritional interests and concerns of the male and female athletes in this study were different. Separate nutrition education sessions would allow the nutrition educator to address specific needs of the athletes which are more likely to be similar and of interest to the whole group if groups are divided by gender and sport.

For a short term study, it is suggested that research focusses on the effect of nutrition education related to only one variable. An attempt to cover anthropometrics, nutrition 
knowledge and dietary intake is not impossible but difficult.

Finally, it is recommended that nutrition intervention be on-going. Effects of nutrition education will be better assessed if the same population is studied and followed for a longer period of time and acquisition of nutrition knowledge and practice changes far more likely. 


\section{R E F E R E N C E S}

1. Henderson D. Nutrition and the athlete. FDA Consumer 1987;87:2219.

2. Short SH, Short WR. Four-year study of university athletes' dietary intake. J Am Diet Assoc 1983;82:632-645.

3. Enns MP, Drewnowski A, Grinker JA. Body composition, body size estimation, and attitudes towards eating in male college athletes. Psychosom Med 1987;49:56-64.

4. Clark N. Case studies in sports nutrition. Phys Sportsmed 1988;16:131-141.

5. Lineback DR. Nutrition (diet) and athletics. J Chem Ed 1984;61:536-539.

6. Wolf EMB, Wirth JC, Lohman TG. Nutrition practices of coaches in the big ten. Phys Sportsmed 1979;7:113-124.

7. Worme JD, Doubt TJ, Singh A, Ryan CJ, Moses FM, Deuster PA. Dietary patterns, gastrointestinal complaints, and nutrition knowledge of recreational triathletes. Am J Clin Nutr 1990;51:690-697.

8. Welch PK, Zager KA, Endres J, Poon SW. Nutrition education, body composition, and dietary intake of female college athletes. Phys Sportsmed 1987;15:63-74.

9. Werblow JA, Fox HM, Henneman A. Nutrition knowledge, attitudes, and food patterns of women athletes. J Am Diet Assoc 1978;73:242-245.

10. Parr RB, Porter MA, Hodgson SC. Nutrition knowledge and practice of coaches, trainers, and athletes. Phys Sportsmed 1984;12:127-138.

11. Tuck MB. Nutrition education for coaches and athletes: implications for home economics. Illinois Teacher 1988;6:57-58.

12. Perron M, Endres J. Knowledge, attitudes, and dietary practices of female athletes. J Am Diet Assoc 1985;85:573-576.

13. Eck LH, Anspaugh DJ, Roach RR, Rosato F, Fox L. Composition of training table selections in a group of male university athletes. Athl Train 1988;23(2);141-144.

14. Steen SN, McKinney S. Nutrition assessment of college wrestlers. Phys Sportsmed 1986; $14: 100-116$. 
15. Shoaf LR, McClellan PD, Birskovich KA. Nutrition knowledge, interests, and information sources of male athletes. J Nutr Educ 1986;18:243-245.

16. Chery A, Sabry JH, Woolcott DM. Nutrition knowledge and misconceptions of university students: 1971 vs. 1984 . J Nutr Educ 1987;19(5):237-241.

17. Hickson JF, Schrader J, Trischler LC. Dietary intakes of female basketball and gymnastics athletes. J Am Diet Assoc 1986;86:251-253.

18. Hickson JF, Wolinsky I, Pivarnik JM, Newman EA, Itak JF, Stockton JE. Nutritional profile of football athletes eating from a training table. Nutr Res 1987;7:27-34.

19. Williams MH. Nutritional ergogenic aids and athletic performance. Nutr Today 1989;24:7-14.

20. Pratt CA, Walberg JL. Nutrition knowledge and concerns of health and physical education teachers. J Am Diet Assoc 1988;88:840-841.

21. Nowak RK, Knudsen KS, Schulz LO. Body composition and nutrient intakes of college men and women basketball players. J Am Diet Assoc 1988;88:575-578.

22. Barr SI. Nutrition knowledge of female varsity athletes and university students. J Am Diet Assoc 1987;87(12):1660-1664.

23. Novascone MA, Hertzler AA. Perception of nutrient density and information links of college students. J Am Diet Assoc 1986;86:94-95.

24. National Dairy Council: Nutrition Achievement Test 4. Rosemont: National Dairy Council, 1986.

25. Grandjean AC. Macronutrient intake of U.S. athletes compared with the general population and recommendations made for athletes. Am J Clin Nutr 1989;49:10701076.

26. Nutrition for physical fitness and athletic performance for adults: Technical support paper. J Am Diet Assoc 1987;87:934-939.

27. Marrale JC, Shipman JH, Thodes ML. What some college students eat. Nutr Today 1986;21:16-21.

28. Hernon JF, Skinner JD, Andrews FE, Penfield MP. Nutrient intakes and foods selected by college students: comparisons among subgroups divided by energy intake. J Am Diet Assoc 1986;86(2):217-221. 
29. Hertzler AA, Frary RB. Food behavior of college students. Adolesc 1989;24(94):349356.

30. Harvey JS. Nutritional management of the adolescent athlete. Clin Sports Med 1984;3(3):671-678.

31. Burckes-Miller ME, Black DR. Eating disorders: a problem in athletics? Health Educ 1988;19(1):22-25.

32. Food Power: A Coach's Guide to Improving Performance. Rosemont: National Dairy Council, 1988.

33. Aronson V. Vitamins and minerals as ergogenic aids. Phys Sportsmed 1986;14:209212.

34. Millard-Stafford M, Rosskopg LB, Sparling PB. Coronary heart disease: risk profiles of college football players. Phys Sportsmed 1989;17(9):151-163.

35. Franke NVT. A comparison of the effect of three different nutrition education methods on the nutrition knowledge, attitudes, and practices of female university student-athletes. Dissertation Abstracts International 1989;50(3):631A.

36. Updegrove NA, Johnson RM. Using table tents to present sports nutrition facts to collegiate athletes. J Nutr Ed 1987;19:302D.

37. Short SH. Dietary surveys and nutrition knowledge, in Nutrition in Exercise and Sport, Hickson JF, Wolinsky I, ed. CRC Press, Boca Raton: Florida, 1989.

38. Rosen LW, McKeag DB, Hough DO, Curley V. Pathogenic weight-control behavior in female athletes. Phys Sportsmed 1986;14(1):79-86.

39. Burckes-Miller ME, Black DR. Male and female college athletes: prevalence of anorexia nervosa and bulimia nervosa. Athl Train 1988;23(2):137-140.

40. University of Miami Hurricanes: 1990 Official Football Media Guide. Miami: Swanson Printing Co., 1990.

41. Fact Sheet for the Chairman, Subcommittee on Postsecondary Education, Committee on Education and Labor, House of Representatives. Student Athletes: Information on Their Academic Performance. Washington: U.S.General Accounting Office, 1989. 
42. Eisenman PA, Johnson SC, Benson JE. As the caliper turns, in Coaches Guide to Nutrition and Weight Control. 2nd. edition. Champaign: Leisure Press, 1990.

43. Woteki CE. Methods for surveying food habits: how do we know what Americans are eating? Clin Nutr 1986;5(1):9-16.

44. Marcus JB. Nutrition and physical assessment, in Sports Nutrition: A Guide for the Professional Working with Active People. Chicago: American Dietetic Association, 1986.

45. Stunkard AJ, Waxman M. Accuracy of self-reports of food intake. J Am Diet Assoc 1981;79:547-551.

46. Gay LR. The experimental method, in Educational Research: Competencies for Analysis and Application. 3rd. edition. Columbus: Merrill Publishing Co., 1987.

47. Software: Computrition. Computerized Single User System. Chatsworth: Computrition Inc., 1989.

48. Leverton RM. The RDAs are not for amateurs. J Am Diet Assoc 1975;66:9-11.

49. Committee on Dietary Allowances, Food and Nutrition Board, National Research Council. Recommended Dietary Allowances. 10th. edition. Washington: National Academy Press, 1989. 


\section{NUTRITION ACHIEVEMENT TEST \\ ADAPTED FROM \\ THE NUTRITION ACHIEVEMENT TEST 4 (NAT 4) \\ BY THE NATIONAL DAIRY COUNCIL}

\section{ABOUT THE TEST}

This test contains 28 multiple choice questions. It will take 15 to 25 minutes. Each question has four possible answers. One answer is better than any of the others.

Fill in the information on your answer sheet.

\section{Directions:}

Read each question carefully. Select the one best answer and record it. Answer all questions. Choose the answer which seems best even if you are not sure. Do not leave any questions unanswered.

Complete the sample question below:

Sample question:

1. Which is not a food?
a) olives.
b) soap.
c) grape leaves.
d) cereal.

If you chose (b) soap, your answer is correct.

If you are not clear on how to proceed, ask your instructor to explain.

When your instructor tells you to begin, turn to the test and start with question 1. 


\section{APPENDIX A}

1. What would be the safest way to lose weight?

a) Drink 8 glasses of water each day and eat only fruits and vegetables.

b) Reduce caloric intake by skipping lunch.

c) "Fast" for three days and then begin exercising.

d) Reduce caloric intake and increase physical activity.

2. The best way to decide if your weight is in an appropriate range is to compare to:

a) your parents' weights when they were your age.

b) national charts of desirable weights at your height and age.

c) the amount of food you eat.

d) your friends' weights.

3. Your best friend says a candy bar is the best snack for energy so he eats at least one a day. You say:

a) Candy bars have a lot of sugar which eats up your energy.

b) This is true since candy bars have a lot of sugar.

c) Other snacks provide energy and greater amounts of other nutrients at the same time.

d) Candy bars provide calories, not energy.

4. What would you need to know about the "Seven Day" weight reduction diet before you could decide if it was safe?
a) That it provides all the essential nutrients you need.
b) That you could still eat your favorite foods.
c) That it recommends exercising as a part of the diet.
d) How much it will cost.

5. How does your level of activity relate to the number of calories you need to keep a constant weight?
a) If you rarely exercise you need more calories.
b) If you don't eat much you need more calories.
c) If you exercise a lot you need more calories.
d) If you are very active you need fewer calories.

6. What is meant by the statement: " $\mathrm{X}$ " is more nutritious than " $\mathrm{Y}$ "?
a) " $\mathrm{X}$ " is fresher than " $\mathrm{Y}$ ".
b) "X" has more of the important nutrients than " $Y$ ".
c) "X" has more vitamins and "Y" has more minerals.
d) " $\mathrm{X}$ " has fewer calories than "Y". 


\section{APPENDIX A}

7. Total caloric needs are determined mostly by:

a) basal metabolism and amount of physical activity.

b) your doctor.

c) the way you play sports.

d) your weight and how much you eat.

8. Television ads often influences our food choices. They do all the following except:

a) tell you of food products that are available.

b) make you hungry for that product.

c) give complete nutritional information.

d) use pretty girls and handsome guys to attract attention.

9. With his friends after school, Mike usually fills up on sweets, skips supper because he is still full and then snacks again in the evening. How can Mike best improve his food habits without changing his whole lifestyle?

a) Starting the next day, eliminate all sweets and eat three meals a day.

b) Stop getting together with friends after school.

c) Change one food habit a week to gradually improve his diet.

d) Take diet aids sold at the drugstore so he won't be hungry after school.

10. How could you find out if you might have too few or too many nutrients in your diet?

a) Determine the amount of fat you have on your body.

b) Analyze the nutritive value of the food you eat over a period of time.

c) Count the number of calories you consume each day.

d) Determine if your height and weight are normal for your age.

11. What would be most important when planning a diet for athletes?

a) Add large doses of vitamins to the diet.

b) Decrease protein intake.

c) Avoid snacks.

d) Plan adequate energy intake.

12. Tony was eating lunch in the school cafeteria. Although he had never tried corn bread, he didn't take any because his friends said it wasn't good. Which of the following statements would be the most correct reason Tony did not eat the corn bread?
a) If his friends don't like it, probably it isn't good for him.
b) Corn bread does not taste good.
c) Friends often influence one's food choices.
d) People the same age generally have the same tastes. If his friends don't like it, Tony won't either.




\section{APPENDIX A}

13. Where could you go to find how many grams of protein are recommended for your daily diet?
a) A food label.
b) The RDA tables.
c) The dictionary.
d) A list of foods you have eaten today.

14. Which of the following foods is a good source of protein?
a) Bread.
b) Corn flakes.
c) Eggs.
d) Green beans.

15. What negative effect might TV viewing have on the eating habits of a person?
a) Seeing the commercials for products like candy or soda pop often makes a person want them even when not hungry.
b) Commercials show you what new food products are on the market.
c) Many commercials give nutritional information about a food product.
d) A documentary report on food might tell you why a food product isn't good for you.

16. Much research is being conducted on the connection between diet and disease. Yet, scientist do not always agree on the results. In the absence of definite research findings, wheat would be the best way to plan your diet?
a) Eliminate all foods which have been questioned in these studies.
b) Eat whatever you want until the scientific community reaches agreement.
c) Don't eat food with additives.
d) Don't eat an excess of foods in question.

17. At home Bob tries to avoid foods low in nutrients. Yet when he is at a party with friends he doesn't think about it and eats whatever is available. What best explains the reason for the difference in his eating habits?
a) There is probably no nutritional value in the food he eats when he's with friends so there isn't any point in thinking about it.
b) Bob's friends serve only nutritious foods.
c) Bob does not need to worry about eating foods low in nutrients.
d) The social setting he's in often influences the types of food he eats. 


\section{APPENDIX A}

18. What is the most important thing to remember when seeing or listening to an advertisement for a food product?
a) Industry is interested in selling a product.
b) Ads are trying to educate the public about nutrition.
c) Information presented in ads is unbiased.
d) Only ads comparing two products are accurate.

19. The easiest way to determine the nutrients provided by a new food product is to
a) read the list of ingredients on the label.
b) look up the food product in a list of new foods.
c) write the manufacturer.
d) read the nutrition information panel on the label.

20. The RDA tables help in planning diets because they
a) recommend the amount of nutrients needed.
b) list what to eat, how much and when.
c) tell what foods are not good for us.
d) recommend foods good for certain organs.

21. How could you compare the nutritive value of frozen orange juice and powdered orange flavored breakfast drink?
a) Watch television commercials.
b) Read the nutrition level.
c) Use your common sense.
d) Taste for sweetness of the juice.

22. What information is most often printed on food packages?
a) Cost of the product per ounce.
b) Cooking of food preparation instructions.
c) The ingredients and weight.
d) Statement telling how good the food is for you.

23. Louis has started playing racquetball two hours a day. How will he need to change his food intake if he wants to maintain the same weight?
a) Eat a lot of candy.
b) Eat less since he will be more active.
c) Consume more calories.
d) Have extra calcium so his bones won't break. 
24. A father and his 12-year-old son both want to lose weight. Their weight loss plans would be different because
a) they have different nutritional requirements.
b) the father shouldn't exercise.
c) the son might get sick easily.
d) they like different foods.

25. An advertisement suggested that taking a vitamin and mineral supplement would lead to superior athletic ability. Which statement is true?
a) The supplement is needed to increase endurance.
b) Vitamins and minerals have little to do with athletic performance.
c) Supplements are not needed if body needs for vitamins and minerals are met through diet.
d) Supplements are the best way for athletes to get those nutrients.

26. Alcohol is one type of drug as well as a food. Large consumption of alcoholic beverages affects nutritional status because alcohol
a) increases the body's absorption of nutrients.
b) causes hunger so one consumes more nutrients than the body needs.
c) provides many nutrients so one must cut down on food intake.
d) exerts a diuretic effect which tends to promote the excretion of some minerals and vitamins.

27. Tom is trying to lose weight. His friends are going to a fast food restaurant after school for a snack. He doesn't want to break his diet. The best advice would be to
a) tell his friends he can't go.
b) go and order french fries and a soda instead of a hamburger.
c) go and eat what they are eating since he can start his diet again later.
d) go and order orange juice.

28. What is the best information source for the nutrient content of a fabricated food?
a) a taste test.
b) the advertising promotion.
c) a label containing nutrition information.
d) friends who have eaten the product. 
APPENDIX B

\section{3-DAY DIET RECORD}

NAME

DON'T FORGET TO INCLUDE:

SNACKS!

DATE

MAYO, CATSUP, BUTTER...!

VITAMIN, MINERAL..SUPPLEMENTS!

USE ONE FORM FOR EACH DAY

\begin{tabular}{|c|c|c|c|c|}
\hline TIME & $\begin{array}{c}\text { FOOD ITEM } \\
\text { Be as specific as possible }\end{array}$ & $\begin{array}{l}\text { QUANTITY } \\
\text { (oz, slices, } \\
\text { cups, tsps) }\end{array}$ & $\begin{array}{l}\text { DESCRIPTION } \\
\text { (fried,raw, } \\
\text { boiled,etc) }\end{array}$ & $\begin{array}{l}\text { WHERE } \\
\text { EATEN }\end{array}$ \\
\hline & & & & \\
\hline & & & & \\
\hline & & & & \\
\hline & & & & \\
\hline & & & & \\
\hline & & & & \\
\hline & & & & \\
\hline & & & & \\
\hline & & & & \\
\hline & & & & \\
\hline & & & & \\
\hline & & & & \\
\hline & & & & \\
\hline & & & & \\
\hline & & & & \\
\hline & & & & \\
\hline & & & & \\
\hline & & & & \\
\hline & & & & \\
\hline
\end{tabular}


APPENDIX B

\begin{tabular}{|c|c|c|c|c|}
\hline TIME & $\begin{array}{c}\text { FOOD ITEM } \\
\text { Be as specific as possible }\end{array}$ & $\begin{array}{l}\text { QUANTITY } \\
\text { (oz, slices, } \\
\text { cups, tsps) }\end{array}$ & $\begin{array}{c}\text { DESCRIPTION } \\
\text { (fried,raw, } \\
\text { boiled,etc) }\end{array}$ & $\begin{array}{l}\text { WHERE } \\
\text { EATEN }\end{array}$ \\
\hline & & & & \\
\hline & & & & \\
\hline & & & & \\
\hline & & & & \\
\hline & & & & \\
\hline & & & & \\
\hline & & & & \\
\hline & & & & \\
\hline & & & & \\
\hline & & & & \\
\hline & & & & \\
\hline & & & & \\
\hline & & & & \\
\hline & & & & \\
\hline & & & & \\
\hline & & & & \\
\hline & & & & \\
\hline & & & & \\
\hline & & & & \\
\hline & & & & \\
\hline & & & & \\
\hline & & & & \\
\hline & & & & \\
\hline
\end{tabular}




\section{LESSON NO. 1}

LESSON PLAN: General nutrition principles for athletes.

GENERAL OBJECTIVES: Athletes will be aware of sports nutrition myths and able to identify energy nutrients (carbohydrates, protein, fat) given food examples.

\section{BEHAVIORALOBJECTIVES AND FEEDBACK MECHANISMS:}

1.1 Athletes will recognize common myths in sports nutrition as erroneous.

1.2 Athletes will identify energy nutrients provided by the basic four food groups.

\section{KNOWLEDGE:}

1.1.1 Myth: "Athletes need salt tablets."

1.1.2 Myth: "A high calorie, high protein intake will increase muscle size and provide energy."

1.1.3 Myth: "Water causes upset stomach and cramps."

1.1.4 Myth: "High protein, high fat foods make a great pregame meal."

1.2.1 Variety is the purpose of the basic four food groups.

1.2.2 Carbohydrates, protein and fat are sources of energy.

1.2.3 Alcohol provides energy (calories) but no nutrients.

1.2.4 Carbohydrates are the main source of energy in the diet for athletes.

\section{LEARNING EXPERIENCES:}

1.1 Lecture (talk) presenting the concepts of sports nutrition and common myths.

1.2 Lecture (talk) on energy nutrients.

Discussion and demonstration of food sources of carbohydrates, protein and fat using food models.

\section{TEACHING AIDS AND TECHNIQUES:}

1.1 Charts.

Video: "Sports Nutrition: Fueling a Winner" (Introduction and nutrition myths sections).

1.2 Charts.

Food models. 
APPENDIX C

\section{LESSON NO. 2}

LESSON PLAN: Pre-game meals and fluid replacement.

GENERAL OBJECTIVES: Athletes will be aware and recognize importance of pre-game meals and fluid replacement.

\section{BEHAVIORALOBJECTIVES AND FEEDBACK MECHANISMS:}

2.1 Athletes will suggest pre-game meals with appropriate food choices.

2.2 Athletes will mention the importance of fluid replacement and point out advantages of water over sports drinks.

\section{KNOWLEDGE:}

2.1.1 There is no magic to the food of a pre-game meal.

2.1.2 Foods eaten days before an event will have an effect on performance.

2.1.3 Hunger prevention is the purpose of the pre-game meal.

2.1.4 Foods high in carbohydrates are the best choice for a pre-game meal.

2.2.1 Drink water before, during, and after an event or practice session.

2.2.2 Undiluted sports drinks remain in the stomach longer than water.

2.2.3 If sports drinks are used, they need to be diluted with water.

\section{LEARNING EXPERIENCES:}

2.1 Recitation and discussion on pre-game meals and their importance. Demonstration and guided practice on how to choose an appropriate pre-game meal with food models.

2.2 Lecture (talk) on importance of water intake. Recitation by asking athletes what they know about sport drinks.

\section{TEACHING AIDS AND TECHNIQUES:}

2.1 Charts.

Food models.

2.2 Charts.

Handouts. 


\section{LESSON NO. 3}

LESSON PLAN: Fast foods.

GENERAL OBJECTIVES: Athletes will make appropriate food choices and identify main nutrients and hidden sources of fat for fast food selections.

\section{BEHAVIORALOBJECTIVES AND FEEDBACK MECHANISMS:}

3.1 Athletes will identify hidden sources of calories, fat and sodium for fast food choices.

3.2 Athletes will verbalize means by which calorie content can be reduced for fast food choices.

\section{KNOWLEDGE:}

3.1.1 Fast food advertisement is concerned with selling products and seldom provides nutrition information.

3.1.2 Fast food is high in calories, fat and salt.

3.1.3 Fast food is low in fiber, calcium, vitamins $\mathrm{A}$ and $\mathrm{C}$.

3.2.1 Calories and fat can be reduced by removing or reducing amount of sauces, mayonnaise, dressings, cream cheese, cheese, toppings, butter.

3.2.2 Food habits can be changed one at a time.

\section{LEARNING EXPERIENCES:}

3.1 Discussion and recitation on common fast food choices and their nutrient content.

3.2 Discussion on ways by which calorie content can be reduced for food selections using charts and diagrams.

\section{TEACHING AIDS AND TECHNIQUES:}

3.1 Charts.

Handout.

3.2 Charts.

Diagrams. 
APPENDIX C

\section{LESSON NO. 4}

LESSON PLAN: Healthy food choices: nutrition labeling.

GENERAL OBJECTIVES: Athletes will be able to recognize and use nutrition information on labels for food selection.

\section{BEHAVIORALOBJECTIVES AND FEEDBACK MECHANISMS:}

4.1 Athletes will identify nutrition information on food labels.

4.2 Athletes will suggest more nutritious food samples based upon available nutrition information on labels.

\section{KNOWLEDGE:}

4.1.1 Food labels provide nutrition information including specific nutrients and the amounts of each present per serving.

4.2.1 Food labels give the necessary information to compare the nutrient content of different foods.

4.2.2 The more a food resembles the original, the more nutritious it is likely to be.

4.2.3 Generally, food processing reduces the amount of nutrients, and adds sugar, salt and/or fat (nutrient empty).

\section{LEARNING EXPERIENCES:}

4.1 Recitation by asking athletes what nutrition information is available on food labels.

Lecture (talk) on the importance and usefulness of nutrition information on food labels.

4.2 Discussion on how to select a more nutritious food item upon the information provided on label when comparing different food products.

\section{TEACHING AIDS AND TECHNIQUES:}

4.1 Charts.

Food packages.

4.2 Charts.

Food packages. 
APPENDIX C

\section{LESSON NO. 5}

LESSON PLAN: Nutritional ergogenic aids.

GENERALOBJECTIVES: Athletes will identify the ineffectiveness of nutritional ergogenic aids for athletic performance.

BEHAVIORALOBJECTIVES AND FEEDBACK MECHANISMS:

5.1 Athletes will identify nutritional ergogenic aids and recognize their ineffectiveness given a questionnaire.

\section{KNOWLEDGE:}

5.1.1 Large amounts of protein or amino acid supplements will not increase muscle size and strength.

5.1.2 Athletes do not need extra vitamins.

5.1.3 Salt tablets are not necessary to replace sodium lost from sweating.

5.1.4 Drinking water during practice or competition will not cause upset stomach or cramps.

5.1.5 Milk before and event will not cause "cotton mouth."

5.1.6 Consumption of honey, sugar, soft drinks or a candy bar is not recommended just prior to competition or practice.

\section{LEARNING EXPERIENCES:}

5.1 Recitation by asking athletes what they know about nutritional ergogenic aids.

Discussion on common sports nutrition myths given a questionnaire.

Discussion on reasons why sports nutrition myths are so popular.

\section{TEACHING AIDS AND TECHNIQUES:}

5.1 Charts.

Video: "Sports Nutrition: Fueling a Winner" (Nutrition myths section). Handouts.

Questionnaire. 
APPENDIX C

\section{LESSON NO. 6}

LESSON PLAN: Weight control and body composition.

GENERAL OBJECTIVES: Athletes will recognize the importance of weight maintenance and body composition on athletic performance.

\section{BEHAVIORALOBJECTIVES AND FEEDBACK MECHANISMS:}

6.1 Athletes will identify ways by which optimal weight can be maintained.

6.2 Athletes will verbalize the relationship between their percentage of body fat and the concept of body composition.

\section{KNOWLEDGE:}

6.1.1 Athletes need to balance what they eat against what their bodies use to maintain weight.

6.1.2 Athletes need to eat less, exercise more, or do a combination of the two to lose weight.

6.1.3 Athletes need to eat more, exercise less, or do a combination of the two to gain weight.

6.2.1 Extra weight may be due to body fat or muscle.

6.2.2 Muscle is metabolically active, fat is inactive.

6.2.3 Excess body fat can impair athletic performance.

\section{LEARNING EXPERIENCES:}

6.1 Recitation on what athletes know about weight control.

Lecture (talk) on how to control weight.

6.2 Discussion on roles of muscle and fat in exercise.

Lecture )talk) on body composition.

\section{TEACHING AIDS AND TECHNIQUES:}
6.1 Charts.
Handout.
6.2 Charts. 